\title{
The Working Methods of the International Law Commission: Adherence to Methodology, Commentaries and Decision-Making
}

\author{
Danae Azaria
}

Introduction

In the twenty-first century, the International Law Commission has increasingly moved away from its "codification by convention" paradigm to the preparation of instruments that remain non-binding. ${ }^{1}$ A combination of factors may encourage governments, national courts and international courts and tribunals to rely on the Commission's non-binding outputs. ${ }^{2}$ The Commission's composition is geographically representative of the world's legal systems; the Commission is institutionally required to interact with governments, whose comments find reflection in the Commission's final output; and the quality of the Commission's work addresses a frequent challenge that governments and national and international courts face: collecting and assessing State practice for the purpose of interpreting treaties or identifying rules of customary international law.

This last aspect, the quality of the Commission's work, is inextricably linked with its working methods. Today, the Commission faces numerous challenges that are different from those that existed at the time when the Commission was established. The number of States has almost tripled compared to 70 years ago. The Commission's composition has been enlarged. ${ }^{3}$ More multilateral treaties have been concluded, covering many areas of international law. International courts and tribunals have proliferated and often apply rules of

1 See also Jacob Katz Cogan, 'The Changing Form of the International Law Commission's Work' in Robert Virzo and Ivan Ingravallo (eds), Evolutions in The Law of International Organizations (Martinus Nijhoff 2015), 275; Frank Berman, 'The ILC within the UN's Legal Framework: Its Relationship with the Sixth Committee' (2006) 49 GYIL 107; David D. Caron, 'The ILC Articles on State Responsibility: The Paradoxical Relationship between Form and Authority' (2002) 96 AJIL 857 .

2 See also the Commission's own understanding of these factors: ILC, 'Draft conclusions on the identification of customary international law, with commentaries' (2018) UN Doc A/73/10, 122 at 142 (general commentary to part five, para 2).

3 Since 1981, the Commission's statute provides that the Commission is to be composed of 34 members, see UNGA Res $36 / 39$ (18 November 1981). 
general international law. More national courts engage with international law. ${ }^{4}$ At present, an increasing number of States seem keen to retreat from international law, especially multilateralism.

All of these challenges call for further reflection on the Commission's working methods, in order to preserve and enhance the quality of its work. The following analysis will comment on three issues, taking into account some recent developments. First, the Commission's adherence to methodology will be discussed. Second, the role and preparation of commentaries will be examined. Third, the method of decision-making will be analyzed.

Before embarking on the main discussion, some preliminary comments about the Commission's functions and procedures are warranted. First, the Commission has not developed different procedures depending on the outcome of the topic (a convention or a non-binding instrument $)^{5}$ or depending on the nature of the rules concerned (rules of general scope, such as secondary rules on sources and on State responsibility, or rules that deal with a specific issue, e.g. the protection of the environment in relation to armed conflict). The Commission has instead followed a process that does not turn upon any such differences, and has deviated from this process only on an ad hoc basis. Second, the statute of the Commission is structured upon a distinction between progressive development and codification. Chapter II of the statute contains two separate parts: Part A on the progressive development of international law, and Part B on the codification of international law. ${ }^{6}$ These provide for two distinct procedures for each function. ${ }^{7}$ However, in practice the Commission has mostly not distinguished between these two functions, including in its

$4 \quad$ Eyal Benvenisti, 'Reclaiming Democracy: The Strategic Uses of Foreign and International Law by National Courts' (2008) 102 AJIL 241.

5 See in that regard see the contribution of Maurice Kamto in this Section.

6 Statute of the ILC, UNGA Res 174(II) (21 November 1947) as amended by: UNGA Res 485(v) (12 December 1950); unga Res 984(x) (3 December 1955); Unga Res 985(X) (3 December 1955); and UNGA Res 36/39 (18 November 1981).

7 Compare articles 16 and 17 (on progressive development) to articles 18-24 (on codification). For instance, according to its statute, the Commission lacks the initiative to consider topics on progressive development. The General Assembly, pursuant to article 16 of the Commission's statute, and United Nations Members, the principal organs of the United Nations other than the General Assembly, specialized agencies, or official bodies established by intergovernmental agreement, pursuant to article 17 of the Commission's statute, may refer to the Commission a proposal for progressive development. In relation to codification, the Commission shares the initiative with the General Assembly (article 18), United Nations Members, the principal organs of the United Nations other than the General Assembly, specialized agencies, or official bodies established by intergovernmental agreement (article 17, paragraph 1). In relation to progressive development, the statute expressly 
procedures, because any topic may include both instances of codification and of progressive development to varying degrees.

\section{Consistent Adherence to Methodology}

As mentioned above, the Commission has developed a practice whereby it does not usually classify its output on a topic as either progressive development or codification. Sometimes, the Commission indicates in the introduction to its commentary that there are instances of both in the topic. ${ }^{8}$ Occasionally, it clarifies in the commentary to a specific provision that it represents lex lata ${ }^{9}$ or lex ferenda, and the extent of lex ferenda. ${ }^{10}$

Today, States at times express concern that the lack of differentiation gives the Commission's pronouncements too much authority, since international courts and tribunals assume that all of its pronouncements reflect existing law. ${ }^{11}$ So far, this criticism has not encouraged the Commission to be more expressive in identifying whether its pronouncements fall within codification or progressive development. Perhaps this is because until recent years the Commission has worked on the assumption that most of its work may lead to negotiations for a future convention; and negotiations operate as a "safety net" for States, which can influence the final language of a treaty and are only bound by their consent.

foresees the appointment of a Rapporteur (article 16(a)). However, the statute does not provide for the appointment of a Rapporteur concerning codification. See also analysis by Shabtai Rosenne, 'The International Law Commission, 1949-1959' (1960) 36 BYIL 104.

8 ILC, 'Draft articles concerning the law of the sea, with commentaries' [1956] II ILC Ybk $254,255^{-256}$ at paras $25^{-26}$; ILC, 'Draft articles on responsibility of States for internationally wrongful acts with commentaries thereto' [2001] II(2) ILC Ybk 30, 31(general commentary, para 1).

9 See, for instance, ILC, 'Draft articles on the law of treaties with commentaries' [1966] II ILC Ybk 177, 246 (commentary to article 49, para 1) ("The Commission considers that these developments justify the conclusion that the invalidity of a treaty procured by the illegal threat or use of force is a principle which is lex lata in the international law of today.").

10 See, for instance, ILC, 'Draft articles on responsibility of States for internationally wrongful acts with commentaries thereto' (n 8) 137 (commentary to article 54, para 3) concerning measures taken by States other than the injured State ("Practice on this subject is limited and rather embryonic").

11 See for instance the comments of the following governments in the Sixth Committee concerning the draft articles on immunity of State officials from foreign criminal jurisdiction as provisionally adopted by the Commission in 2017: China (UN Doc A/C.6/72/SR.23, 9), Spain (UN Doc A/C.6/72/SR.24, 7), Switzerland (UN Doc A/C.6/72/SR.22, 12). 
However, in an era where codification through non-binding instruments becomes the main paradigm, ${ }^{12}$ such concerns, ${ }^{13}$ especially from States, may become more pronounced. The Commission may thus be encouraged to demonstrate a consistent adherence to methodology. ${ }^{14}$ It may also be encouraged to be more expressive about the results of the application of such methodology.

Thomas Franck argued that rules that are legitimate are more likely to be complied with, and one of the factors that make rules legitimate is their adherence to methodology: in other words, adherence to secondary rules of international law for identifying and interpreting primary rules. ${ }^{15}$ Consistent "adherence" to such secondary rules is an important basis on which the Commission's work is and will be relied upon. This is because adherence to such methodology operates as a restraint on the Commission's discretion: it anchors its output in State practice, opinio juris and international jurisprudence, rather than on mere policy preferences of the Commission's members.

Evidence that the Commission is cognizant that adherence to secondary rules is important for the persuasion of its own work can be found in the Commission's work on customary international law. In 2018, the Commission adopted on second and final reading 16 draft conclusions on the identification of customary international law. ${ }^{16}$ The General Assembly took note of the conclusions, annexed them to a resolution, brought them 'to the attention of States and all who may be called upon to identify rules of customary international law, and encourage[d] their widest possible dissemination: ${ }^{17}$ These do not include a draft conclusion specifically dedicated to the Commission's own outputs. Some members of the Commission had suggested including such a conclusion. ${ }^{18}$ However, it was decided not to insert one, but rather to make reference to the Commission in the introductory commentary to part five of the

12 See account of trend in Laurence R Helfer and Timothy Meyer, "The Evolution of Codification: A Principal-Agent Theory of the International Law Commission's Influence' in Curtis Bradley (ed), Custom's Future: International Law in A Changing World (cup 2016) 305 .

13 Michael Wood, "Weighing' the Articles on Responsibility of International Organizations' in Maurizio Ragazzi (ed), The Responsibility of International Organizations. Essays in Memory of Sir Ian Brownlie (Brill 2013) 55 at 65-66.

14 Laurence R Helfer and Timothy Meyer, 'The Evolution of Codification: A Principal-Agent Theory of the International Law Commission's Influence' (n 12) 305 .

15 Thomas Franck, Fairness in International Law and Institutions (ou P 1995) 30, 40-46.

16 ILC, 'Draft conclusions on identification of customary international law, with commentaries' ( $\mathrm{n} 2$ ).

17 UNGA Res 73/203 (20 December 2018).

18 ILC, 'Report of the International Law Commission on the work of its sixty-seventh session' (2015) UN Doc A/70/10, 47 at para 104. 
conclusions entitled "Significance of certain materials for the identification of customary international law". That commentary introduces some qualitative criteria for the reliance on the Commission's work. It states that the Commission's determinations "may have particular value [flowing from, inter alia] the thoroughness of its procedures (including the consideration of extensive surveys of State practice and opinio juris); and its close relationship with the General Assembly and States (including receiving oral and written comments from States as it proceeds with its work)."19 It concludes that "the weight to be given to the Commission's determinations depends [...] on various factors, including the sources relied upon by the Commission, the stage reached in its work, and above all upon States' reception of its output". ${ }^{20}$

Further, conclusion 14, entitled "Teachings", recognizes that teachings may constitute a subsidiary means for determining rules of customary international law. The commentary to conclusion 14 introduces some crucial criteria for teachings to be used as a subsidiary means for determining rules of customary international law. The Commission states that "assessing the authority of a given work is essential $[\ldots]^{21}$ for it to be a subsidiary means for the determination of rules of law. "The value of each output [of an international expert body] needs to be carefully assessed in the light of the mandate and expertise of the body concerned, the extent to which the output seeks to state existing law, the care and objectivity with which it works on a particular issue, the support a particular output enjoys within the body, and the reception of the output by States and others". 22 These criteria apply to outputs by the Commission as well. ${ }^{23}$ What the Commission calls "care and objectivity" in this topic, Thomas Franck called "adherence".

19 ILC, 'Draft conclusions on the identification of customary international law, with commentaries' (n 2) 142 (general commentary to part five, para 2) (emphasis added).

20 Ibid (emphasis added).

21 Ibid 151 (commentary to draft conclusion 14 para (3)).

22 Ibid (commentary to conclusion 14, para 5) (emphasis added).

23 The commentary to draft conclusion 14 does not refer to the Commission, but to "international expert bodies". As examples of such bodies, it mentions the Institut de Droit international and the International Law Association. These bodies differ from the Commission, which is a subsidiary organ of an international organisation and has a direct relationship with governments. Footnote 774 of the Commission's report in the commentary to conclusion 14 states that " $\mathrm{t}]$ he special consideration to be given to the output of the International Law Commission is described in paragraph (2) of the general commentary to the present Part (Part Five) above." This does not mean that the general requirements for other collective expert bodies would not apply to the Commission's determinations. As indicated above, paragraph (2) of the commentary to part five also refers to some (nonexhaustive) qualitative criteria, which overlap with the "care and objectivity" referred in the commentary to conclusion 14: e.g. "the sources relied upon". 
The Commission's recent work on how international law may be identified and interpreted, whether in the context of the law of treaties, customary international law, or jus cogens, and in the future with respect to general principles of law, ${ }^{24}$ should be consistently used by the Commission not only for codification, but also for progressive development: as the method for determining the existence or non-existence of rules and their content, as well as the stage of their development. The secondary rules systematized by the Commission for those topics are invaluable for the Commission itself: they should consciously guide the Commission's work, if the Commission is to maintain and even enhance its influence.

\section{Commentaries}

In the commentaries, the Commission explains the draft text, such as draft articles, draft conclusions, draft guidelines or draft principles, with references to practice, judicial decisions and doctrine. This is important because in doing so, the Commission provides evidence of the "care and objectivity" in its reasoning. For instance, the commentaries to the 2011 guide to practice on reservations to treaties ${ }^{25}$ and to the 2018 conclusions on subsequent agreements and subsequent practice in relation to the interpretation of treaties ${ }^{26}$ are indicative of the methodology that the Commission employs when it interprets the Vienna Convention on the Law of Treaties. ${ }^{27}$ Adherence to the rules on treaty interpretation may persuade States to entertain the Commission's interpretative pronouncements.

However, commentaries are also crucial for the identification and interpretation of rules, particularly by judicial actors. The following analysis demonstrates the role and importance of commentaries in judicial practice. In order to be methodologically thorough and comprehensive, the analysis focuses on the decisions of the International Court of Justice. It shows that the Court

24 ILC, 'Report of the International Law Commission on the work of its seventieth session' (2018) UN Doc A/73/10, 299 at para 363.

25 ILC, 'Guide to practice on reservations to treaties, comprising an introduction, the guidelines and commentaries thereto, an annex on the reservations dialogue and a bibliography' [2011] II(3) ILC Ybk 23.

26 ILC, 'Draft conclusions on subsequent agreements and subsequent practice in relation to the interpretation of treaties and commentaries thereto' (2018) UN Doc A/73/ $10,12$.

27 See detailed analysis in Danae Azaria, 'Codification by Interpretation': The International Law Commission's Interpretative Activity and Method (forthcoming). 
relies heavily on the commentaries adopted by the Commission (section 1). In light of these findings, it is surprising how very little (if any) literature exists on the significance of commentaries and on the method of their preparation and adoption. For this reason, the analysis then moves on to the manner in which commentaries are prepared and adopted; it reflects on and assesses some contemporary methods of preparing commentaries; and makes some suggestions for improving the method of preparation of commentaries that are adopted by the Commission (section 2).

\section{1 \\ The Significance of Commentaries in the Decisions of the International Court of Justice}

Commentaries have considerable legal significance, which is demonstrated by the number of instances in which international courts and tribunals have relied on them. Research in this regard focused on the decisions of the International Court of Justice is quite telling.

As of 30 August 2018, the International Court of Justice has relied expressly on the Commission's work in 22 cases (19 decisions in contentious proceedings and 3 advisory opinions). ${ }^{28}$ In each case, the Court relies on the Commission's

28 Contentious Proceedings: North Sea Continental Shelf Cases (Federal Republic of Germany/Denmark; Federal Republic of Germany/The Netherlands) [1969] ICJ Rep 3, paras 48-50, 54-55, 95; Continental Shelf (Tunisia v Libya) [1982] ICJ Rep 18, paras 41, 100, 119; Military and Paramilitary Activities in and against Nicaragua (Nicaragua v United States) (Merits) [1986] ICJ Rep 14, 100 at para 190; Gabčḱkovo-Nagymaros Project (Hungary/ Slovakia) [1997] ICJ Rep 7, paras 47, 50-54, 58, 123; Land and Maritime Boundary between Cameroon and Nigeria (Cameroon v Nigeria) (Preliminary Objections) [1998] ICJ Rep 275, para 31; Kasikili/Sedudu Island (Botswana v Namibia) (Merits) [1999] ICJ Rep 1045, para 49; Maritime Delimitation and Territorial Questions between Qatar and Bahrain (Qatar $v$ Bahrain) (Merits) [2001] ICJ Rep 40, para 113; Land and Maritime Boundary between Cameroon and Nigeria (Cameroon v Nigeria; Equatorial Guinea intervening) (Merits) [2002] ICJ Rep 303, para 265; Armed Activities on the Territory of the Congo (Democratic Republic of Congo $v$ Uganda) (Merits) [2005] ICJ Rep 168, paras 16o, 293; Application of the Convention on the Prevention and Punishment of the Crime of Genocide (Bosnia and Herzegovina $v$ Serbia and Montenegro) (Merits) [2007] ICJ Rep 43, paras 173, 186, 199, 344, 385, 398, 420, 431; Territorial and Maritime Dispute between Nicaragua and Honduras in the Caribbean Sea (Nicaragua v Honduras) (Merits) [2007] ICJ Rep 659, para 280; Ahmadou Sadio Diallo (Guinea v Democratic Republic of Congo) (Preliminary Objections) [2007] ICJ Rep 582, paras 39, 64, 84, 91, 93; Maritime Delimitation in the Black Sea (Romania v Ukraine) (Merits) [2009] ICJ Rep 61, para 134; Pulp Mills on the River Uruguay (Argentina v Uruguay) [2010] ICJ Rep 14, para 273; Maritime Dispute (Peru v Chile) [2014] ICJ Rep 3, paras 112-117; Jurisdictional Immunities of the State (Germany v Italy; Greece intervening) (Merits) [2012] ICJ Rep 24, paras 56, 69, 89, 137; Obligations concerning Negotiations relating to Cessation of the Nuclear Arms Race and to Nuclear Disarmament (Marshall Island v India) (Jurisdiction and Admissibility) [2016] ICJ Rep 255, para 42; Obligations 
work to address a range of legal questions, and may also use more than one document for each legal question. All told, the Court has relied on Commission documents in relation to 39 different legal questions. Among these, it relied on the commentaries in 13 cases (out of 22 ) 29 and in relation to 21 legal questions (out of 39). Of these 21 legal questions, the Court relied exclusively on the commentary in 11 instances.

concerning Negotiations relating to Cessation of the Nuclear Arms Race and to Nuclear Disarmament (Marshall Islands v United Kingdom) (Preliminary Objections) [2016] ICJ Rep 833, para 45; Certain Activities carried out by Nicaragua in the Border Area (Costa Rica $v$ Nicaragua) (Compensation owed by the Republic of Nicaragua to the Republic of Costa Rica) 2 February 2018 <https://www.icj-cij.org/en/case/15o/judgments>, para 151. Advisory Opinions: Interpretation of the Agreement of 25 March 1951 between the WHO and Egypt (Advisory Opinion) [1980] ICJ Rep 73, paras 47, 49-50; Differences Relating to Immunity from Legal Process of a Special Rapporteur of the Commission on Human Rights (Advisory Opinion) [1999] ICJ Rep 62, para 62; Legal Consequences of the Construction of a Wall in the Occupied Palestinian Territory (Advisory Opinion) [2004] ICJ Rep 136, 175, 176, 195 at para 140.

29 Military and Paramilitary Activities in and against Nicaragua (Nicaragua v United States) (n 28) 100 at para 19o; Gabčíkovo-Nagymaros Project (Hungary/Slovakia) (n 28) paras 50-54, 123; Land and Maritime Boundary between Cameroon and Nigeria (Cameroon v Nigeria) (n 28) para 31; Kasikili/Sedudu Island (Botswana v Namibia) (n 28) para 49; Land and Maritime Boundary between Cameroon and Nigeria (Cameroon v. Nigeria; Equatorial Guinea intervening) (n 28) para 265; Armed Activities on the Territory of the Congo (Democratic Republic of Congo v Uganda) (n 28) para 293; Application of the Convention on the Prevention and Punishment of the Crime of Genocide (Bosnia and Herzegovina $v$ Serbia and Montenegro) (n 28) paras 173, 186, 199, 344; Territorial and Maritime Dispute between Nicaragua and Honduras in the Caribbean Sea (Nicaragua v Honduras) (n 28) para 280; Maritime Delimitation in the Black Sea (Romania v Ukraine) (n 28) para 134; Jurisdictional Immunities of the State (Germany $v$ Italy; Greece intervening) (n 28) paras 56, 69; Obligations concerning Negotiations relating to Cessation of the Nuclear Arms Race and to Nuclear Disarmament (Marshall Island $v$ India) (n 28) para 42; Obligations concerning Negotiations relating to Cessation of the Nuclear Arms Race and to Nuclear Disarmament (Marshall Islands $v$ United Kingdom) (n 28) para 45; Certain Activities carried out by Nicaragua in the Border Area (Costa Rica v Nicaragua) (n 28) para 151. Bosnia and Herzegovina $v$ Serbia and Montenegro and Germany $v$ Italy include instances where the Court relied on the commentary to identify customary international law, and on separate occasions as a supplementary means of treaty interpretation. They are not counted twice among the 13 cases referred. However, in the breakdown below they appear in relation to instances where the Court used the Commission's commentary in relation to treaty interpretation and to custom identification. Marshall Islands $v$ India and Marshall Islands $v$ United Kingdom are the two cases that do not fall within these two classifications; but within the instances where the Court has used the Commission's commentary in order to interpret the draft provision without taking a position about customary international law or using it for treaty interpretation. 
In seven cases the Court treated the commentaries as a supplementary means of treaty interpretation. In six of these cases, it relied on them as preparatory works of a treaty. ${ }^{30}$ In one case, Application of the Convention on the Prevention and Punishment of the Crime of Genocide (Bosnia and Herzegovina $v$ Serbia and Montenegro), the Court relied on the commentary of the 1996 Draft Code of Crimes against the Peace and Security of Mankind in order to interpret the 1948 Genocide Convention, a treaty which had been concluded almost 50 years earlier and in whose drafting the Commission had not been involved. ${ }^{31}$ In six cases, the Court relied on the commentaries in order to identify a rule of customary international law. ${ }^{32}$

As a separate matter, as Judge Gaja has persuasively argued, since the Commission adopts draft provisions together with commentaries, the commentaries constitute the context in which draft provisions are to be interpreted. ${ }^{33}$ This can be important in practice. In Marshall Islands $v$ India, and Marshall Islands $v$ United Kingdom (2016), India and the United Kingdom objected to the Court's jurisdiction. They both argued that article 43 of the 2001 articles on the responsibility of States for internationally wrongful acts requires the injured State (and by analogy States other than the injured State) to give notice of its claim to the allegedly responsible State. Since the Marshall Islands had not done so, the respondents argued that there was no dispute and as a result the Court lacked jurisdiction. ${ }^{34}$ The Court rejected this argument. By relying

$30 \quad$ Land and Maritime Boundary between Cameroon and Nigeria (Cameroon v Nigeria) (n 28) para 31;Kasikili/Sedudu Island (Botswana v Namibia) (n 28) para 49; Land and Maritime Boundary between Cameroon and Nigeria (Cameroon v Nigeria; Equatorial Guinea intervening) (n 28) para 265; Territorial and Maritime Dispute between Nicaragua and Honduras in the Caribbean Sea (Nicaragua v Honduras) (n 28) para 280; Maritime Delimitation in the Black Sea (Romania v Ukraine) (n 28) para 134; Jurisdictional Immunities of the State (Germany v Italy; Greece intervening) (n 28) para 69.

31 Application of the Convention on the Prevention and Punishment of the Crime of Genocide (Bosnia and Herzegovina $v$ Serbia and Montenegro) (n 28) para 186.

32 Military and Paramilitary Activities in and against Nicaragua (Nicaragua v United States) (n 28) para 19o; Gabčikovo-Nagymaros Project (Hungary/Slovakia) (n 28) paras 50-54, 58, and 123; Armed Activities on the Territory of the Congo (Democratic Republic of Congo $v$ Uganda) (n 28) para 293; Application of the Convention on the Prevention and Punishment of the Crime of Genocide (Bosnia and Herzegovina $v$ Serbia and Montenegro) (n 28) para 173; Jurisdictional Immunities of the State (Germany v Italy; Greece intervening) (n 28) para 56; Certain Activities carried out by Nicaragua in the Border Area (Costa Rica v Nicaragua) (n 28) para 151.

33 Giorgio Gaja, 'Interpreting Articles Adopted by the International Law Commission' (2016) 85 BYIL 10.

34 Obligations concerning Negotiations relating to Cessation of the Nuclear Arms Race and to Nuclear Disarmament (Marshall Island v India) (n 28) para 32; Obligations concerning 
on the commentary to article 44, the Court found that the articles are not concerned with issues of jurisdiction or admissibility of claims. ${ }^{35}$ In other words, the Court interpreted article 43 in the context of the commentary to article 44.

The significance of the commentaries cannot be greater than that of the draft articles, draft guidelines, draft conclusions or draft principles adopted by the Commission, though commentaries may shed important light on them. However, the fact that the Court has relied on the commentaries in more than half of the decisions where it has relied on the Commission's work overall shows that commentaries play a crucial role in judicial practice. In light of these findings, the method of their preparation and adoption deserves close scrutiny.

\section{2}

\section{Preparation and Adoption of Commentaries}

This section briefly describes the Commission's usual working methods and its interaction with governments through the Sixth (Legal) Committee of the United Nations General Assembly focusing on the consideration and preparation of commentaries (section a). Then, it provides some reasons for which the Commission ought to reconsider its current approaches to the preparation of commentaries and makes some proposals that may assist the Commission in drafting commentaries in a timely fashion. More specifically, it discusses the time at which the Commission considers and adopts commentaries (section b), the usefulness of working groups on commentaries (section c), and the implications of publicising the Drafting Committee's draft articles that are not accompanied by commentaries (section d). It touches on a recent development which involves the preparation of commentaries only after the Drafting Committee has adopted provisionally a complete set of draft provisions over a number of years (section e), before summarizing some suggestions about the approach that the Commission may wish to adopt vis-à-vis the preparation of commentaries (section $\mathrm{f}$ ).

Overview of Working Methods Concerning the Preparation and Adoption of Commentaries

The procedures of the Commission have changed over the years, but currently they usually take the following form. When introducing a topic in its

Negotiations relating to Cessation of the Nuclear Arms Race and to Nuclear Disarmament (Marshall Islandsv United Kingdom) (n 28) paras 27-28.

35 Obligations concerning Negotiations relating to Cessation of the Nuclear Arms Race and to Nuclear Disarmament (Marshall Island v India) (n 28) para 42; Obligations concerning Negotiations relating to Cessation of the Nuclear Arms Race and to Nuclear Disarmament (Marshall Islandsv United Kingdom) (n 28) para 45. 
programme of work, the Commission decides whether to appoint a Special Rapporteur. Once appointed, the Special Rapporteur prepares and submits her or his report(s), which include her or his proposals backed by her or his analysis, to be considered by the Commission's plenary, where proceedings are public. In plenary, members of the Commission comment on the Special Rapporteur's report. The Commission in plenary decides whether the proposals are to be referred to the Drafting Committee. If so, the Drafting Committee meets (in closed session) in order to prepare and provisionally adopt draft texts (being draft articles, conclusions, guidelines or principles), which it then submits to plenary for approval, along with draft commentaries prepared by the Special Rapporteur. At each session the Commission (in plenary) provisionally adopts on first reading the draft texts proposed by the Drafting Committee, although it only does so when commentaries on the draft texts are available at that session. Otherwise it only takes note of the draft texts prepared by the Drafting Committee. This process repeats itself in subsequent years based on subsequent reports of the Special Rapporteur, until such time as a complete set of draft articles (or conclusions, guidelines or principles) is completed, at which point they are adopted as a whole on first reading.

The Commission's progress on the topics it considers annually is recorded in its annual report, which is submitted to the General Assembly. The General Assembly considers the Commission's annual report each year in the Sixth Committee, which is composed of delegates of all United Nations Member States, who may comment on the Commission's annual report. The Special Rapporteur and the Commission take into account governments' comments in the following sessions of the Commission. Usually oral comments on first reading draft texts and commentaries are only taken into account (along with written comments made to the first reading) in preparation of the second reading.

If and when a full set of draft articles (or conclusion, guidelines or principles) is adopted on first reading by the Commission (in plenary), the Commission submits it along with commentaries to the General Assembly. The Commission also invites written comments from governments, usually providing about fifteen months for submissions. After the written submissions are received, the Special Rapporteur produces a final report that revisits the draft articles and commentaries adopted on first reading, taking into account the comments of governments making proposals for changes. The proposed changes are then debated in the plenary, which may refer them to the Drafting Committee. When the Commission in plenary finally adopts the draft articles on second reading along with commentaries, the Commission concludes its 
work on the topic. It submits the draft articles together with commentaries to the General Assembly, making a recommendation concerning the future treatment of the document. ${ }^{36}$

The reports of Special Rapporteurs are the prime tool by which the Commission develops its work in plenary and the Drafting Committee. They are also, together with the comments in plenary and the discussions in the Drafting Committee, a springboard for the preparation of the commentaries. The Special Rapporteur, and the quality of her or his report are central to the progress of a topic. The Special Rapporteur offers a service to the Commission and to the Commission's collegiate output.

The Drafting Committee, owing to its function, informality and limited composition, ${ }^{37}$ also makes an important contribution. The negotiations are painstakingly detailed and may revolve around technical drafting, legal substance or material that may support the one or the other possible formulation. Ideally, the Drafting Committee should be involved in the preparation of the commentary to a provision in parallel with the draft provision, because very often language in the commentaries may ease agreement about the formulation of a particular draft provision. However, because of its workload, the Drafting Committee does not produce commentaries. ${ }^{38}$ Rather, the usual practice is that the Special Rapporteur prepares and revises the commentary after the Drafting Committee provisionally adopts draft texts. In doing so, he or she takes account of what has been said in the Drafting Committee. In some instances, commentaries have been prepared on the basis of consideration in a separate working group.

Usually the Commission (in plenary) considers commentaries at the end of its session (in August). For those topics considered in the first part of the

36 Following adoption by the Commission of a document on second (and final) reading, governments are invited to make comments in the Sixth Committee, which also prepares a General Assembly resolution about the handling of the text and which may decide to reconsider this issue at a future session.

37 In 1992, the Commission recommended that in order for the Drafting Committee to operate efficiently, it should not have more than 14 members, taking into account representative composition. Other members may observe, but should exercise constraint in their comments, see [1992] II(2) ILC Ybk paras 371 and 373. However, members of the Commission can be part of the Drafting Committee on any topic. The Drafting Committee's composition for some topics is up to 25 members. See 'Report of the International Law Commission on the work of its sixty-ninth session' (2017) UN Doc A/ $72 / 10,2$ at para 6 .

38 ILC, 'Report of the International Law Commission on the work of its forty-eighth session' [1996] II (2) ILC Ybk 1, 92 at para 199. 
Commission's session (usually in May), the Special Rapporteur has time to prepare commentaries (to the draft articles provisionally adopted by the Drafting Committee) during the break in the Commission's session and submit them for consideration and adoption in the second half of the Commission's session. However, for those topics that are considered in the second part of the Commission's session (in July), there is usually insufficient time for the Special Rapporteur to prepare the commentaries and for the plenary to consider them on time. As explained above, the Commission does not adopt draft texts (articles, conclusions, guidelines or principles) without commentaries. In such cases, the Commission merely takes note of draft texts provisionally adopted by the Drafting Committee. However, since 2012, the Drafting Committee's report that is presented by its Chair in plenary and contains these draft texts becomes publicly available. ${ }^{39}$ This development has encouraged governments in the Sixth Committee to react to the Drafting Committee's provisionally adopted draft texts (without there being commentaries on them).

Building on these trends, in relation to some topics, a new approach has occasionally been followed: draft texts are kept in the Drafting Committee annually, and the Special Rapporteur prepares the commentary, once the Drafting Committee has adopted all draft texts on a topic. All draft texts and commentaries are then adopted by the plenary on first reading. The conclusions on identification of customary international law were prepared in this way (over a two-year period without adopting commentaries) and adopted on first reading (2016). In this particular case, the approach was followed owing to time constraints and on an exceptional basis, and with the consideration of commentaries by a working group before their consideration and adoption in plenary.$^{40}$ However, the approach of preparing and adopting commentaries only

39 The first quotation of draft provisions adopted provisionally by the Drafting Committee appeared in 2012: The draft articles on the protection of persons in the event of disasters provisionally adopted by the Drafting Committee were quoted in a footnote in the Commission's report. ILC, 'Report of the International Law Commission on the work of its sixty-forth session' (2012) UN Doc A/67/10, 85 at footnote 275 .

40 The Commission considered the first report of the Special Rapporteur (UN Doc A/CN.4/ $663)$ in 2013. The Special Rapporteur only proposed draft conclusions in his second report (UN Doc A/CN.4/672) (2014) and his third report (UN Doc A/CN.4/682) (2015), and proposed amendments to the conclusions provisionally adopted by the Drafting Committee in his fourth report (UN Doc A/CN.4/695 and Add.1) (2016). In 2014, the Commission only dealt with the report of the Special Rapporteur in the second half of its session which meant that the Drafting Committee dealt with this topic late in the Commission's session leaving no time for commentaries to be prepared and adopted by the Commission. ILC, 'Report of the International Law Commission on the work of its sixty-sixth session' (2014) UN Doc A/69/10, 238 at paras 135-136. In 2015, the discussion 
once the whole set of draft texts is prepared and adopted has been proposed for other topics as a matter of preference. In relation to the topic peremptory norms of general international law (jus cogens), the Special Rapporteur has indicated his preference not to draft commentaries before the whole set of draft conclusions is provisionally adopted by the Drafting Committee. ${ }^{41}$ No commentaries have been considered by the Commission on this topic for three years while draft provisions have been provisionally adopted by the Drafting Committee. ${ }^{42}$

of the topic began in the first part of the Commission's session, but owing to the importance of commentaries in general, the Special Rapporteur proposed that "if the Drafting Committee was able to complete its work this session, and provisionally adopt a complete set of draft conclusions [...], [he] could then prepare draft commentaries on all the conclusions in time for the beginning of the 2016 session. Members would then have adequate time to consider the draft commentaries carefully," so that the full set of first reading draft conclusions and commentaries could be adopted by the Commission by the end of its 2016 session. ILC report 2015 (n 24), p. 48 at para 107. In 2016, the commentary was discussed in a Working Group early in the first half of the Commission's session (May 2016). ILC, 'Report of the International Law Commission on the work of its sixtyeighth session' (2016) UN Doc A/71/10, p 75 at para 58.

Dire Tladi, 'Third report on peremptory norms of general international law (jus cogens)' (2018) UN Doc A/CN.4/714, 4 at para 11 ("The Special Rapporteur has indicated his preference that the draft conclusions remain with the Drafting Committee and, for that reason, they have not been referred to the plenary"; emphasis added). The statement of the Chair of the Drafting Committee (14 May 2018) also indicates that "[i]n line with the Special Rapporteur's recommendation, made in 2016, the draft conclusions remain in the Drafting Committee until the full set has been adopted so that the Commission will be presented with a full set of draft conclusions before taking action." Peremptory norms of general international law (jus cogens), Statement of the Chairperson of the Drafting Committee, Oral interim report, Mr. Charles Chernor Jalloh, 14 May 2018, p 1, available at: http://legal.un.org/docs/?path=../ilc/documentation/english/statements/ 2018_dc_chairman_statement_jc.pdf\&lang=E. Upon the concerns expressed by some Commission members, the Special Rapporteur recounted that " $[\mathrm{t}]$ he topic had always been considered in the second part of the Commission's annual session" thus making it impossible to have commentaries considered in plenary. See UN Doc A/CN.4/ SR. 3425,3 .

The Commission considered the first report of the Special Rapporteur (UN Doc A/CN.4/ 693) (2016) in the second half of its session, and the Drafting Committee provisionally adopted three draft conclusions. ILC Report 2016 (n 40), 297 at paras 98-101. In his second report (2017), the Special Rapporteur proposed six more draft conclusions (UN Doc A/CN.4/706) (2017) and the Drafting Committee provisionally adopted draft conclusions in the second half of the Commission's session. ILC Report 2017 (n 37), 192 at paras 144147. In 2018, in the first half of the Commission's seventieth session (2018), the Drafting Committee provisionally adopted draft conclusions 8 and 9 , which had been proposed by the Special Rapporteur in his second report that the Drafting Committee considered in the previous session (2017). The Commission also considered in the first and second 
Having set out the Commission's main working methods and latest developments, the following sections further assess some of the practices vis-à-vis commentaries.

\section{The Time of Consideration of Commentaries}

As noted above, the Commission adopts commentaries in plenary usually at the end of its session. Considering commentaries so late during the session introduces considerable time pressure and little opportunity for debate. It could be argued that Commission members have ample opportunity to consider commentaries in detail before they are adopted on second reading. However, courts and tribunals have relied upon draft articles and commentaries adopted on first reading. A paradigmatic example is the reliance of the International Court of Justice in Gabčikovo-Nagymaros Project (1997) on the Commission's draft articles on responsibility of States for internationally wrongful acts adopted on first reading. ${ }^{43}$ Further, even on second reading, commentaries are usually considered at the end of the Commission's session and adopted under time pressure.

If the Commission decreased the number of topics on its programme of work, there would be more time for Commission members to consider commentaries in further detail prior to the consideration in plenary as well as in plenary. As a separate matter, the use of working groups dedicated to the drafting of commentaries may allow for more thorough consideration by Commission members prior to the debate in plenary. This issue is further discussed below (section c).

\section{Working Groups on Commentaries}

Working groups have occasionally assisted in the preparation of commentaries. For instance, the commentaries to the articles on responsibility of States for internationally wrongful acts were prepared on second reading by the Special Rapporteur and were commented on by a number of members in a working group. ${ }^{44} \mathrm{~A}$ recent example is the working group for the commentary to

half of its session the third report of the Special Rapporteur (UN Doc A/CN.4/714 and Corr.1), who proposed 13 additional draft conclusions. ILC Report 2018 (n 24), 224-227 at paras 94-97.

43 Gabčḱkovo-Nagymaros Project (Hungary/Slovakia) (n 28) paras 47, 50-54, 58. Domestic courts have also done so. For instance, the English Court of Appeal in The Freedom and Justice Party and Orsv The Secretary of State for Foreign and Commonwealth Affairs referred to the draft conclusions on the identification of customary international law adopted on first reading: [2018] EWCA Civ 1719, 19 September 2018, para. 18.

44 ILC, 'Report of the International Law Commission on the work of its fifty-third session' [2001] II(2) ILC Ybk 1, 21 at para 43. 
the conclusions on the identification of customary international law, which worked in the first part of the Commission's session in 2016 and assisted the Special Rapporteur to prepare a commentary to the whole set of conclusions. The commentary was prepared in time for and was adopted in the second half of the Commission's session that year.

Such a working group format does not negotiate or prepare commentaries. It assists the Special Rapporteur in light of the enormous amount of material to be assessed. It also allows members of the Commission to thoroughly examine drafts of the commentaries and have some ownership over them. In this way, it enables consensus and saves time in plenary. For these reasons, it may be worth using this process further. However, the working group procedure does not necessarily entail and should not be understood as preventing members of the Commission that participate in the working group from scrutinising the commentaries in plenary, ${ }^{45}$ where discussions are public, allowing for further clarification of the commentaries.

\section{Publicizing the Report of the Drafting Committee Without Commentaries}

As explained above, since 2012, the statements of the Chair of the Drafting Committee, which summarize the debate of the Drafting Committee and present the draft provisions that the Drafting Committee has provisionally adopted, are made publicly available. This publicity has encouraged governments to read the Drafting Committee's adopted texts and react to them in the Sixth Committee. In light of these reactions, the Special Rapporteur and the Drafting Committee may make further changes before draft texts and commentaries are adopted on first reading.

On the other hand, the texts that are provisionally adopted by the Drafting Committee are currently referred to in the annual reports of the Commission in an inconsistent manner. At times the annual report quotes in a footnote the text provisionally adopted by the Drafting Committee. ${ }^{46}$ On other occasions,

45 See the concern voiced by Shinya Murase in his contribution to this Section that members may not be willing to repeat in plenary the views they expressed in a working group.

46 For example, in the 2015 report, the draft articles on immunities of State officials from foreign criminal jurisdiction and the draft principles on the protection of the environment in times of armed conflict, both provisionally adopted by the Drafting Committee, are quoted verbatim (ILC report 2015 (n 18) 116 at footnotes $389-390$ and 105 at footnotes $377^{-}$ 378 , respectively). In the 2016 report, the draft principles on the protection of the environment in relation to armed conflict and the draft guidelines on provisional application of treaties, provisionally adopted by the Drafting Committee, are also quoted verbatim (ILC report 2016 (n 40), 308 at footnote 1309 and 365 at footnote 1454, respectively). 
the annual report only cites the Commission's webpage without quoting the draft text and without citing the precise webpage where the specific document is located. Rather the reader must look for the document in the website of the Commission. ${ }^{47}$ This inconsistency takes place not only from annual report to annual report, but also within the same annual report. ${ }^{48}$

This is not merely an editorial point or only a point about making more easily accessible the documents cited in the annual report of the Commission. It indicates that it is unclear whether States in the Sixth Committee comment on the Drafting Committee's output, which may be quoted verbatim in a footnote in the report or cross-referred to, or whether they only respond to the provisions proposed by the Special Rapporteur, which are usually also quoted in the Commission's report. ${ }^{49}$ If States comment on the Special Rapporteur's report, time is lost, because the Drafting Committee often has revised the Special Rapporteur's proposals. If instead they comment on draft provisions of the Drafting Committee without reference to commentaries, States fail to consider the commentaries of these draft provisions, which give explanations and evidence of State practice and authorities, and which constitute the context in which draft provisions are to be interpreted, as explained in section 1

47 As an example, the 2017 report does not quote the draft conclusions on peremptory norms of general international law (jus cogens) or draft articles on succession of States in respect of State responsibility, provisionally adopted by the Drafting Committee, but it cites the Commission's webpage, which means that in order to find the statement of the Chair of the Drafting Committee appending them one needs to look for the page of a particular topic and find the list of reports of the Drafting Committee. (ILC report 2017 (n 37) 193 at footnote 809 , and 203 at footnote 817 , respectively).

48 The 2015 report of the Commission cites the webpage of the Commission, thus directing the reader to look for the statement of the Drafting Committee's Chair, which appends the provisionally adopted draft conclusions on identification of customary international law and the provisionally adopted draft guidelines on provisional application (ILC report 2015 (n 18) 40 at footnote 76 and 131 at footnote 395, respectively). However, in the same report, the draft articles on immunities of State officials from foreign criminal jurisdiction and the draft principles on the protection of the environment in times of armed conflict, both provisionally adopted by the Drafting Committee, are quoted verbatim (ILC report 2015 (n 18) 116 at footnotes 389-39o and 105 at footnotes $377-378$, respectively). The 2016 report of the Commission quotes verbatim the draft principles on the protection of the environment in relation to armed conflict and the draft guidelines on provisional application of treaties, provisionally adopted by the Drafting Committee (ILC report 2016 (n 40), 308 at footnote 1309 and 365 at footnote 1454, respectively). However, it only cites the the webpage of the Commission, thus directing the reader to look for the statement of the Drafting Committee's Chair, which appends the draft conclusions on jus cogens provisionally adopted by the Drafting Committee (ibid 297 at footnote 1289).

ILC report 2015 (n 18) 39 at footnote 75; ILC report 2017 (n 37) 192-193 at footnote 808. 
above. Their comments do not reflect on the Commission's expert analysis, and may be abstract, politicized and unhelpful. This may also result in further political considerations being introduced in the Commission's work and in further politicising the internal work and output of the Commission before the Commission has even formulated its detailed expert analysis in commentaries. $^{50}$

Preparing Commentaries Only Once the Drafting Committee Provisionally Adopts a Complete Set of Draft Provisions

As explained above (section a), there seems to be some interest in adopting a policy of preparing commentaries only once a complete set of draft articles (or conclusions, guidelines, principles) is adopted. Such an approach builds on some practices of the Commission (sections a to d). For instance, it is coupled with the practice of making publicly available the Drafting Committee's provisionally adopted draft articles. The advantages of and concerns about such practice (explained in section d) apply equally to preparing commentaries only once the whole set of draft articles have been prepared. Although it facilitates the updating of draft articles and commentaries by taking into account governments' comments prior to adoption of the draft articles on first reading, the comments of governments may be politicized and unhelpful, because governments have not considered the commentary, which is the context of the draft articles.

The Commission's statute requires that when the Commission submits to the General Assembly draft texts it must do so with commentaries. In relation to progressive development, article $16(\mathrm{~g})$ of the Commission's statute, which deals with the preliminary work before governments submit comments, refers to "explanations and supporting material". In relation to codification, article 20 , which deals with the stage before governments submit comments, refers to "commentary"; article 21(1), which is also relevant to the stage prior to the comments of governments, refers to "explanations and supporting material"; and article 22, which deals with the stage after governments have given comments, refers to "explanatory report". This terminology does not entail documents that are different in substance to what in the Commission's practice is called "commentary".

One way of interpreting these provisions is that the Commission is required to prepare commentaries only once the Commission has adopted the whole

50 For an empirical assessment of how world politics affect the Commission's function: Jeffrey Morton, The International Law Commission of the United Nations (University of South Carolina Press 2000) 74-101. 
set of draft texts on a topic on first reading. Pursuant to this interpretation, making available for information only the Drafting Committee's provisionally adopted texts without commentaries is compatible with the statute, because the Commission has not yet adopted any text (on first or second reading). However, it may be argued that such an interpretation may not be consistent with the spirit of the statute. The statute establishes two aspects whose interaction leads to the progressive development of international law and its codification. The Commission represents the scientific/expert aspect of progressive development of international law and its codification. The governments, through the General Assembly, represent the political aspect. The statute requires the Commission (the expert aspect) to submit draft texts to the General Assembly together with commentaries, so that governments (the political aspect) reflect and comment on the outputs and reasoning of the expert aspect. Thus, when the General Assembly has sight of draft texts, whenever that may be, it should be with commentary on the draft text.

In addition, if commentaries are considered at the end of the Commission's work on a topic after numerous years, the preparation of commentaries may be too distant from, and they may not be given a role in the drafting process in the Drafting Committee. They cannot assist consensus through explanation of a draft provision. Further, nuances expressed when the draft provisions are adopted may be lost, owing to a significant passage of time between the adoption of a draft provision by the Drafting Committee and when the commentaries are written and adopted perhaps years later. ${ }^{51}$ Additionally, if the Special Rapporteur changes (or indeed other Commission members change), either within the same quinquennium or between quinquennia, the memory of the details of the reasoning of the Drafting Committee that were meant to be reflected in the commentaries may be lost. Moreover, when the Commission, after a few years of considering a topic, does consider the commentaries (under time pressure in the end of the Commission's session), Commission members will have insufficient time thoroughly to consider, reflect and comment on the commentary. Finally, when the Commission adopts commentaries on first reading (after the passage of a considerable period of time), States will face a large amount of material in the commentary. Normally, they will have just over a year to give written comments. This may be challenging, even for States with a large legal staff in their ministries of foreign affairs, let alone those States that do not have such capacity.52

\footnotetext{
51 See also statement by Mr. Murase in plenary, UN Doc A/CN.4/SR.3418, 14.

$5^{2}$ Similar concern expressed in the Commission by Mr. Nolte, UN Doc A/CN.4/SR.3417, 15 .
} 

Interim Conclusions

The Commission ought to consider systemically the role, preparation and adoption of commentaries as a matter of priority, given their importance in judicial practice, and their importance for the Commission itself.

It is of paramount importance to provide conditions for a meaningful review of commentaries by Commission members. The basic condition for such meaningful scrutiny is to give members of the Commission sufficient time to consider the commentaries before the debate and adoption in plenary, and to allow sufficient time for a debate in plenary specifically dedicated to commentaries.

Further, working groups for the consideration of commentaries is a useful practice: it assists the Special Rapporteur in their preparation, it allows Commission members to be thoroughly involved in the consideration of commentaries, and it enables consensus and saves time in plenary. However, it should not be understood or employed as a practice that pre-empts the scrutiny of commentaries in plenary.

Finally, the Commission occasionally takes note of the Drafting Committee's report for topics considered in the second half of its session for which commentaries have not yet been prepared. The report of the Drafting Committee is presented and is made public annexing the draft texts provisionally adopted by the Drafting Committee but without commentaries. This should remain an exceptional practice, and may be addressed by reevaluating the number of topics on which the Commission works during its annual sessions.

The Commission ought to avoid establishing, as a matter of new policy, a practice whereby commentaries are only prepared at the end of its consideration of a topic on first reading. A systematic practice that follows such an approach for numerous years (or between quinquennia, when the Commission's composition changes) may deprive commentaries of their role in enabling consensus, runs the risk of losing the detailed context that the Drafting Committee intended to give to a draft text (be that a draft article, conclusion, guideline or principle), and does not facilitate the genuine interaction of the Sixth Committee with the Commission, since governments react to draft texts without considering the explanations of such provisions in the commentary, which constitutes the context of such draft provisions. If the Commission requires more time for the drafting of commentaries, it may be better to reconsider the number of topics it works on during its annual sessions, rather than considering and preparing the commentaries at the end of the drafting process. If nonetheless the Commission follows such an approach, it will be essential that the commentaries are considered in a working group so as to ensure that 
Commission members have sufficient opportunity to consider the significant amount of material in the commentary.

\section{Method of Decision-Making: between Vote and Consensus}

Rule 125 of the rules of procedure of the General Assembly provides that decisions of committees shall be made by majority of the members present and voting. It applies equally to the International Law Commission, and governs decisions of the Commission in plenary to refer texts to the Drafting Committee, the decisions in the Drafting Committee, and the decisions to adopt texts in plenary on first and second reading.

In the early years of the Commission's life, decisions were often taken by vote. Since the 1970s, however, the Commission has predominantly taken decisions by consensus; only exceptionally has it resorted to a vote. It should not come as a surprise that the Commission moved to consensual decision-making in the 1970s, in the aftermath of the North Sea Continental Shelf case in 1969. In its judgment in this case, the International Court of Justice had found that the "status of the rule [set forth in Article 6] of the [Geneva] Convention [as customary or not] depended mainly on the processes that led the Commission to propose it". ${ }^{33}$ The Court noted that some doubts had been voiced in the Commission about whether the equidistance principle was a customary rule, and concluded that Article 6 of the Geneva Convention had not crystallized into rule of customary international law. ${ }^{54}$

The latest example where the Commission resorted to a vote was in 2017 , in relation to draft article 7 of the draft articles on the "immunity of State officials from foreign criminal jurisdiction", ${ }^{55}$ which concerns exceptions to immunity of State officials. Before then, some instances from 1981 to 2017 where the Commission resorted to vote are the following: (a) in 2009 two indicative votes took place in plenary in relation to reservations to treaties (on first reading); ${ }^{56}(\mathrm{~b})$ in

53 North Sea Continental ShelfCases (Federal Republic of Germany/Denmark; Federal Republic of Germany/The Netherlands) (n 28) para 62 (emphasis added).

54 Ibid.

$55 \quad$ ILC report 2017 (n 37) 164 at para 74.

$5^{6}$ The first vote was taken before referring to the Drafting Committee the proposals of the Special Rapporteur concerning a draft guideline on the statement of reasons for interpretative declarations. The Special Rapporteur had requested the vote and it was decided not to include such a guideline. The second indicative vote was after the Drafting Committee's work on that topic during that session; on the basis of the vote it was decided not to include in draft guideline 3.4.2 a provision concerning jus cogens in relation to 
2008 , a vote was taken in plenary on the topic of reservations to treaties concerning the amendment of a guideline on the procedure for communication of reservations (on first reading); ${ }^{57}$ (c) in 1981, a vote was taken about the definition of "State debt" in article 30 of the draft articles on succession of States in respect of State property, archives and debts (on second reading). ${ }^{58}$

Consensus and voting are valid ways of decision-making. However, both come with consequences concerning the Commission's process, its documentation, as well as more generally the authority (the persuasive force) of the adopted output.

In case of a decision on the basis of a vote, a question may arise as to whether the views of the majority and the minority will be reflected in the Commission's documents, and especially the commentaries. Article $20(\mathrm{~b})$ of the Commission's statute determines the content of the commentaries on first reading, and paragraph (b) expressly includes "divergencies and disagreements which exist, as well as arguments invoked in favour of one or another solution". Article 22 of the Commission's statute, which is concerned with the second reading, requires the Commission to submit to governments "a final draft and explanatory report" taking into account the comments of governments on the documents submitted by the Commission on first reading pursuant to article 20 . The Secretariat has suggested that while article 20 of the Commission's statute indicates that commentaries shall contain inter alia "divergencies and disagreements which exist, as well as arguments invoked in favour of one or another solution", different views are only recorded in the commentaries on first reading but not on second reading, "which reflect only the decisions and positions taken by the Commission as a whole".59 However,

the permissibility of objections to reservations. ILC, 'Report of the International Law Commission on the work of its sixty-first session' [2009] II(2) ILC Ybk, 80 at paras 58 and 6 o.

57 ILC, 'Report of the International Law Commission on the work of its sixtieth session' [2008] II(2) ILC Ybk, 77 at footnote 234.

$5^{8}$ The Commentary on second reading explains that there was a vote and summarises the different views of the members. ILC, 'Draft articles on succession of States in respect of State property, archives and debts, with commentaries' [1981] II(2) ILC Ybk 20, 72 at footnote $319,79-8$ o (commentary to article 31 , paras 45 and 46 ).

59 United Nations, The Work of the International Law Commission, vol I (9th edn, United Nations 2017) 50 at footnote 212; United Nations, The Work of the International Law Commission (8th edn, United Nations 2012), 48 at footnote 202. See also Mr. Dire Tladi (Member of the Commission): Response to his blog post 'Is the International Law Commission Elevating Subsequent Agreements and Subsequent Practice?' (EJIL:Talk!, 31 August 2018) <www.ejiltalk.org/is-the-international-law-commissionelevating-subsequent-agreements-and-subsequent-practice/\#comments >. 
first, the text of article $20(\mathrm{~b})$ does not necessarily refer to divergences and disagreements expressed within the Commission (as opposed to those in State practice, jurisprudence or doctrine). Second, it does not necessarily follow that because article 22 refers to "explanatory report" without expressly referring to differing views, as article 20 does, differing views cannot be recorded in the commentary on second reading; article 22 may be listing the common content of a commentary or explanatory report and no need for repetition was seen fit. Third, there are occasional instances in the Commission's practice where majority and minority views have been discussed in the commentary on second reading. For instance, the commentary to article 47 on the right of hot pursuit of the draft articles concerning the law of the sea, adopted by the Commission on second reading in 1956, records the majority and minority views of members (without recording specifically the names of members taking each view, and without explaining whether a vote had been taken). ${ }^{60}$ Another example is the 1981 vote on second reading concerning the definition of "State debt" in draft article 30 of the draft articles on succession of States in respect of State property, archives and debts: the commentary on second reading explains that there was a vote and summarizes the different views of the members. ${ }^{61}$

As a separate matter, there is a question as to whether a commentary adopted on second reading that demonstrates differences of opinion between members of the Commission may be sufficiently useful to States. In response, it could be said that when differences of opinion persist among members of the Commission, it is likely that these reflect different assessments of State practice, jurisprudence and doctrine and the state of the law. In such situations, the commentary on second reading should reflect these circumstances.

More generally, on the one hand, a vote enables things to move forward. On the other hand, unanimity and consensus indicate common understanding. Indeed, the Commission's widely perceived success story - the 1966 draft articles on the law of treaties - were adopted as a whole by vote. The important detail, however, is that they were adopted by vote unanimously. ${ }^{62}$

The outputs of the Commission are not binding per se. As is the case of the non-binding outputs of expert bodies that have a direct relationship with States, the Commission's non-binding outputs may be influential, because they

6o ILC, 'Articles concerning the Law of the Sea with commentaries' (n 8) 285 (commentary to article 47 , para $2(\mathrm{a})$ ).

61 ILC, 'Draft articles on succession of States in respect of State property, archives and debts, with commentaries' (n $\left.5^{8}\right) 72$ at footnote 319 and $79-8$ o (commentary to article 31 , paras 45 and 46$)$. 
enjoy some "perceived authority" partly owing to the Commission's consistent adherence to methodology and partly owing to the fact that its decisions reflect the common understanding of experts representing the principal legal systems of the world. The common understanding among experts is especially important when it comes to identifying existing rules. But even when the Commission deals with progressive development, its output may be more convincing if it reflects the common understanding of experts as to the development of the law or the most appropriate and harmonious fit with existing rules.

It is perhaps the overt lack of common understanding and disagreement by reference to secondary rules on identifying rules of customary international law that may explain why numerous governments in the Sixth Committee in 2017 expressed a concern about the use of voting by the Commission in relation to a topic as important as exceptions to immunity of State officials from foreign criminal jurisdiction. Of the 61 States that made oral statements concerning the Commission's work, 45 States commented on the draft articles on immunity of State officials from foreign criminal jurisdiction. Of these 45 States, 25 States (more than half of those that made a statement) commented negatively on the use of a vote in the Commission or encouraged the Commission to seek consensus. ${ }^{63}$ Two States took note of the "unusual" method of decision, ${ }^{64}$ and 10 States mentioned the vote without criticizing it. ${ }^{65}$ No State reflected positively on the use of voting.

63 Australia (UN Doc A/C.6/72/SR.22, 13-14 at para 88), China (UN Doc A/C.6/72/SR.23, 9 at para 56), France (UN Doc A/C.6/72/SR.23, 7 at para 42), Germany (UN Doc A/C.6/72/ SR.24, 13 at para 89), Indonesia (UN Doc A/C.6/72/SR.24, 19 at para 130), Iran (UN Doc A/ C.6/72/SR.24, 10 at para 63), Ireland (written statement, 27 October $2017<$ www.papersmart.unmeetings.org/media2/16154683/ireland.pdf> para 3), Israel (UN Doc A/C.6/72/ SR.24, 16 at para 111), Japan (UN Doc A/C.6/72/SR.22, 17 at para 126), Republic of Korea (UN Doc A/C.6/72/SR.24, 15 at para 102), Malawi (UN Doc A/C.6/72/SR.26, 19 at para 136), Norway on behalf of the Nordic Countries (i.e. Finland, Denmark, Iceland and Sweden) (UN Doc A/C.6/72/SR.22, 10 at para 67), Singapore (UN Doc A/C.6/72/SR.22, 15 at para 109), Slovakia (UN Doc A/C.6/72/SR.23, 6 at para 34), Slovenia (UN Doc A/C.6/72/SR.22, 17 at para 129), Spain (UN Doc A/C.6/72/SR.24, 8 at para 42), Sri Lanka (UN Doc A/C.6/72/ SR.23, 8 at para 45), United Kingdom (UN Doc A/C.6/72/SR.24, 10 at paras 57-58), United States (UN Doc A/C.6/72/SR.21, 5 at para 25). Greece (UN Doc A/C.6/72/SR.23, 12 at para 75) did not specifically criticize the method but implicitly considered that the method reflected division in the Commission.

64 Austria (written statement, 26 October $2017<$ www.papersmart.unmeetings.org/media2/ 16154565/austria.pdf>3), Poland (UN Doc A/C.6/72/SR.24, 2 at para 4).

65 Chile (UN Doc A/C.6/72/SR.23, 14), Cuba (UN Doc A/C.6/72/SR.24, 11), Czech Republic (UN Doc A/C.6/72/SR.20, 5), El Salvador (UN Doc A/C.6/72/SR.25, 2), Mexico (UN Doc A/C.6/72/SR.22, 13), Malaysia (written statement, 26 October $2018<$ www.papersmart. unmeetings.org/media2/16154686/malaysia.pdf $>4$ at para 8 ), the Netherlands (UN Doc 
In 1996, the Commission had reviewed its working methods, and had recommended that every effort to achieve consensus should be made, especially in relation to ultimate decisions. It proposed that a vote may be an option if consensus has not been achieved, but after a cooling-off period that allows for more informal deliberation among members of the Commission. ${ }^{66}$ Since then, the Commission has at times established a working group to allow for some progress in cases of disagreement on issues of substance. An example is the Working Group established in relation to the topic "expulsion of aliens" (2008) to consider the issues raised by the expulsion of persons having dual or multiple nationality and by denationalization in relation to expulsion. The Working Group concluded that the commentary should include that for the purpose of the draft articles on expulsion of aliens the principle of non-expulsion of nationals applies also to persons who have legally acquired one or several other nationalities and that wording be inserted to make clear that States should not use denationalization as a means of circumventing their obligation under the principle of non-expulsion of nationals. ${ }^{67}$ The Commission subsequently approved the Working Group's report, and instructed the Drafting Committee to take the conclusions of the Working Group into account.

Such an approach may be wise to ensure that a constructive cooling-off phase is available and that all efforts to achieve a common understanding have been exhausted. ${ }^{68}$ However, disagreement should not freeze the Commission's work. If after a constructive cooling-off period, such as through a working group, disagreement persists, "a vote may be a better indication of the Commission's view than 'a false consensus". ${ }^{69}$

\section{Conclusion}

The Commission's working methods cannot and should not be further abbreviated. They should be expanded and enhanced. The Commission's seventieth anniversary marks a challenging time for international law: when more States

A/C.6/72/SR.24, 5), Peru (UN Doc A/C.6/72/SR.22, 15), Portugal (UN Doc A/C.6/72/SR.22, 12), South Africa (UN Doc A/C.6/72/SR.24, 3).

$66 \quad$ ILC report 1996 (n 38$), 93$ at para 210.

$67 \quad$ ILC report $2008\left(\mathrm{n}_{57}\right) 125$ at para 171.

68 In 2017, France, in its statement in the Sixth Committee, encouraged the Commission to establish a working group in relation to article 7 of the draft articles on immunities of state officials from foreign criminal jurisdiction. UN Doc A/C.6/72/SR.23, 8 at para 43. ILC report 1996 (n 38$) 93$ at para 210. 
seem keen to retreat from international law; and when the challenges for international law as a legal order are new and many: more actors interpret and apply international law with the risk of different pronouncements as to the content of general international law, which may undermine certainty, clarity and predictability. ${ }^{70}$ It is also a time when the Commission's own role might be questioned. ${ }^{71}$ The quality of the Commission's outputs that reflect the common understanding of experts should allow States and international courts and tribunals to continue to rely on the Commission's work. Most importantly, this quality will enable the Commission to fulfil a real and long-term vision: to convince States to continue to use international law as a significant medium by which they regulate their international affairs.

70 Georg Nolte, 'The International Law Commission Facing the Second Decade of the Twenty-First Century' in Ulrich Fastenrath et al (eds), From Bilateralism to Community Interest: Essays in honour of Judge Bruno Simma (oup 2011) 781.

71 Christian Tomuschat, 'The International Law Commission - An Outdated Institution?' (2006) 49 GYIL 77. 